\title{
Impact of Different Mulches on Growth and Yield of Red Okra (abelmoschus esculentus) Indigenous Variety Exposed to Temperature Stress
}

\author{
V. N. A. Godawatte and C. S. De Silva* \\ Department of Agricultural and Plantation Engineering, The Open \\ University of Sri Lanka
}

\begin{abstract}
Understanding the effect of temperature and water stress on growth and yield of crops, and also identifying suitable soil and water management options to sustain the productivity under unexpected changes in the natural environment due to global warming are of timely important. Therefore, the objective of this study is to assess the effect of mulching on soil properties, growth and yield of Red okra (indigenous variety) plants exposed to induced temperature stress to mimic global warming. Experiment was conducted in a temperature regulated poly tunnels with $34^{\circ} \mathrm{C}$ and in the open field with ambient temperature $28-30{ }^{\circ} \mathrm{C}$. Coir dust, straw and saw dust were used as mulch types.
\end{abstract}

Plants were watered to the field capacity daily to minimize the water stress conditions. According to the results, sawdust mulched soil maintained a neutral $\mathrm{pH}$ even at stressful temperature. In temperature stress, sawdust mulch maintained the highest electrical conductivity; it would have enhanced the cooling effect on Red Okra plant roots. Further, the significantly highest plant height was observed in saw dust and straw mulched plants under stressful temperature which improved the vegetative growth of the plants. The highest number of flowers (10) was obtained in straw and saw dust mulched treatments followed by coir mulch (9). The lowest number of flowers was obtained in no mulch condition. Number of pods per plant too follows the similar pattern of number of flowers. However, significantly highest pod weight/yield was obtained at

* Correspondence should be addressed to Prof. C. S. De Silva, Department of Agricultural and Plantation Engineering, Faculty of Engineering Technology, The Open University of Sri Lanka, Sri Lanka (Email: csdes@ou.ac.lk) 
straw mulch (38 g) treatment in stressful temperature. When Green Okra (variety Haritha) was tested in the same poly tunnel with the same experiment conditions but without mulching in a previous season, it showed less number of flowers (8), pods (7) and pod weight $(30 \mathrm{~g})$ for stressful temperature treatments. Further, the Red Okra pods of $20 \mathrm{~cm}$ in length were harvested 5-6 days after flowering even though in ambient temperature, it took 7-8 days. The early harvest in stressful temperature, Red Okra pod yield was 37\% higher than the ambient temperature treatment. But in Green okra (variety Haritha) the pods have to be harvested on 5-6 days in stressful temperature while the pods were just less than $10 \mathrm{~cm}$ which was not preferred by consumers as the edible part is small compared to a $20 \mathrm{~cm}$ long Red Okra pod. This study shows that using suitable mulch such as straw for Red Okra (indigenous variety) could be a viable adaptation measure for dry zone farmers in global warming conditions.

Keywords: Mulch, Temperature stress, Okra red, global warming

\section{Introduction}

The average annual temperature for 2050 using General Circulation Model (HadCM3) is predicted to increase by $1.6{ }^{\circ} \mathrm{C}$ for IPCC (2001) (A2) scenario) and $1.2{ }^{\circ} \mathrm{C}$ (B2) scenario). The highest mean temperature predicted for Anuradhapura is $2.1{ }^{\circ} \mathrm{C}(\mathrm{A} 2), 1.6{ }^{\circ} \mathrm{C}(\mathrm{B} 2)$. During the Southwest monsoon period (May to September), the overall increase in mean annual air temperature across the island is predicted to increase by $1.6{ }^{\circ} \mathrm{C}(\mathrm{A} 1)$ and $1.2^{\circ} \mathrm{C}$ (B2). Agricultural activities in the dry zone may be affected by predicted climate change in Sri Lanka (De Silva, 2006).

Red Okra is an indigenous variety grown in Sri Lanka. Okra is one of the most popular and intriguing vegetables in the Mid-South United States. It not only adds variety, taste and nutrition to Southern cuisine, it is also one of the more reliable crops that farmers and gardeners can grow in a changing climate (Kuepper, 2008). Originating in the African continent, Red Okra is typically heat and drought tolerant, with only a small number of serious diseases and insect pests. Six to seven inches long, torpedo-shaped red or 
burgundy colored Okra pods are tender and rather sweet tasting. Offering a unique flavor and texture, the fresh taste is somewhere between eggplant and asparagus. When cooked, however, the red color disappears and the pods turn green. Raw Red Okra adds a colorful touch to many dishes (Kuepper, 2008).

Red Okra is grown in Wet, Intermediate and Dry zones of Sri Lanka. Presently Red Okra is successfully cultivated in the districts of Hambantota, Kurunagala, Ratnapura and Matale. Also it is expanding in potential districts like Anuradhapura, Puttlam, Matara, Badulla and Moneragala (Department of Agriculture web site). Okra plays an important role to improve the palatability of many dishes and is generally used as nutritional supplements for vitamin $\mathrm{C}$ and $\mathrm{A}, \mathrm{B}$ complex plus magnesium, potassium and calcium. It is fat-free, saturated-fat-free, cholesterol-free and low in calories. (Adebooye and Oputa, 1996).

In the previous study at the Open University with Green Okra (Abelmoschus esculentus) variety Haritha under three temperature conditions as $32{ }^{\circ} \mathrm{C}, 34{ }^{\circ} \mathrm{C}$ and ambient temperature with water stress and no water stress conditions but without mulching, there was significant effect of individual and combination stress of water and temperature on the growth and yield parameters such as plant height, fresh weight and pod length. Significant yield reduction was seen in the water stressed plants. Further temperature stress has especially affected the pod quality parameters such as fibre and pectin content. Harvesting time of Okra under ambient temperature was not suitable for the high temperature conditions due to rapid pod growth rate and break down of the calcium pectate in 5 to 6 days after full blooming. Water and temperature stress in combination had less negative effects on growth parameters as compared to the individual water stress treatments. The high temperature stress in combination with no water stress situation can increase the Green Okra (Variety Haritha) yield significantly compared with other treatments. But the constraints were that the pod has to be harvested in 5-6 days instead of 7-8 days and pods of 5-6 days are very small and not very attractive in the market. Further, under high temperature it is difficult to distinguish the 
exact point for harvesting as the Okra pods quickly matured when it exposed to high temperature stress (Gunawardhana et al., 2011). Therefore, in this study, Red Okra the indigenous variety, with three types of mulching was used to study the coping capacity to induced temperature stress. Red Okra is an indigenous variety the pods are red in colour, torpedo shaped and two to five inches long. It is also called as "Red Burgundy" which grows well in full sunlight and has a year around cultivation.

\section{Materials and Methods}

\section{Growing conditions}

This present study was conducted in the Agricultural field, of the Open University of Sri Lanka, Nawala, Nugegoda using a temperature regulated poly tunnel as one experiment unit. The poly tunnel was maintained at $34{ }^{\circ} \mathrm{C}$ maximum temperature. Second experiment unit was outside the poly tunnel in ambient temperature $\left(28-30{ }^{\circ} \mathrm{C}\right)$. This study was conducted during 2013 November to November 2014. Temperature inside the poly tunnel was maintained $\left(34^{\circ} \mathrm{C}\right)$ through an automated regulatory system.

This study intends to identify the suitable mulch to mitigate the consequences of higher temperature stress on soil by evaluating the growth and yield parameters of Red Okra indigenous variety. The pots were filled with $5 \mathrm{~kg}$ mixture of air dried reddish brown earth soil and compost. 3:1 ratio of soil and compost potting medium used for each pot. Reddish brown earth soil was from the Anuradhapura area (flat land scape) and the depth of the plough layer was 0-30 cm. Three types of mulches (Coir dust, straw and sawdust) were used as an average depth of 2.2 inches of layer spread on the soil surface along with a no mulch condition shortly after sowing (planting). Coir and saw were used as dust form and straw was used by cutting in to $2 \mathrm{~cm}$ of length. Spacing of pots for Okra was $90 \mathrm{~cm} \times 60 \mathrm{~cm}$ as recommended by the Department of Agriculture. Determined parameters of the RBE soil (from Anuradhapura) as $\mathrm{pH}(1: 2.5$, soil: $\mathrm{H}_{2} \mathrm{O}$ ) 7.1, Clay (\%) 27, Silt (\%) 12, Sand (\%) 61, OM (\%) 1.5, $\mathrm{K}(\mathrm{ppm}) 160$ and $\mathrm{P}(\mathrm{mg} / \mathrm{kg}) 20$. Determined the parameters of compost 
used for this research as $\mathrm{pH} 6.8, \mathrm{OM}$ (\%) 32 and conductivity (ms $\left.\mathrm{cm}^{-1}\right) 720$.

Plants were maintained without water stress by applying water to keep the soil moisture at field capacity. Individual plastic pots were filled with compost and reddish brown earth soil mixture. Three seeds were sown in each pot and seedlings were thinned to one plant for each pot 18-25 days after sowing ( 1 plant/ pot in $40 \mathrm{~cm}$ diameter and $45 \mathrm{~cm}$ deep pots). All the crop management and cultural practices were adopted according to the Department of Agriculture.
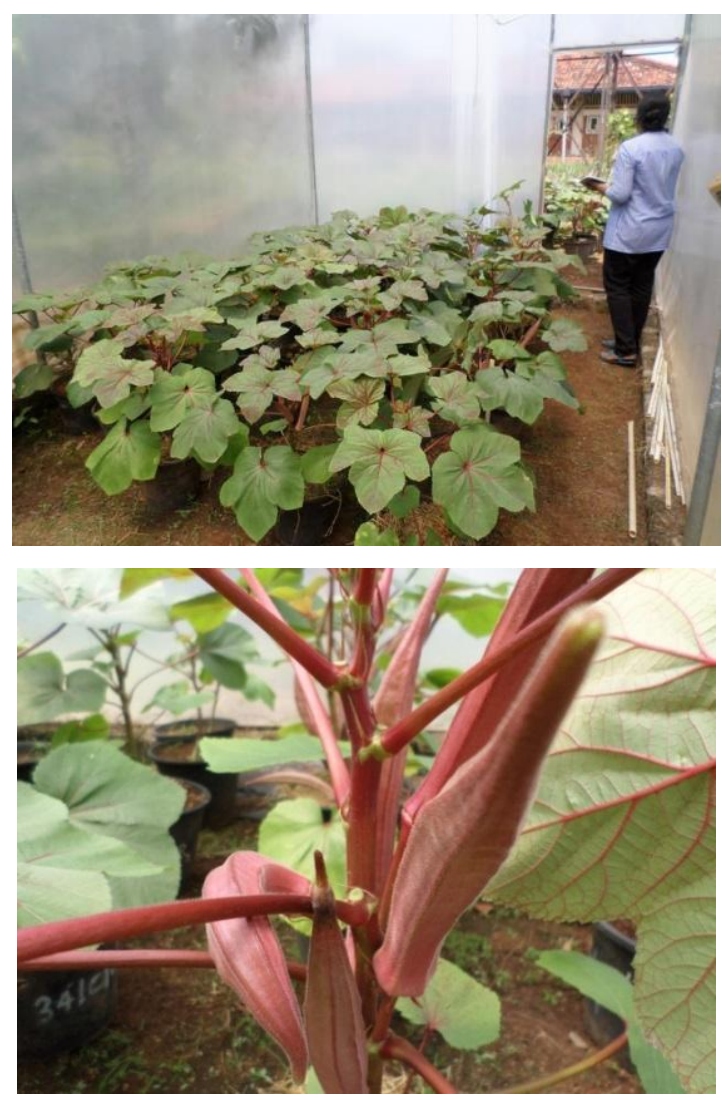

Figure 1. Pot arrangement of Okra 
Table 1. Two different environmental conditions of the experiment

\begin{tabular}{lrl}
\hline No & Environmental conditions \\
\hline Condition $1-$ & $34{ }^{\circ} \mathrm{C}$ Poly tunnel \\
Poly tunnel & $\bullet$ & Three types of mulches on soil - \\
& \multicolumn{2}{c}{ coir dust (M1)/straw (M2)/saw dust (M3)/No mulch(M0) } \\
\hline Condition 2 & $-28-30^{\circ} \mathrm{C} \mathrm{Ambient} \mathrm{temperature}$ \\
Open Space & $\bullet$ & Three types of mulches on the soil - \\
& coir dust (M1)/straw (M2)/saw dust (M3)/No mulch(M0) \\
\hline
\end{tabular}

\section{Temperature control in the poly-tunnels}

The variation of temperature inside the poly tunnel and the ambient temperature outside over a period of 24 hours was observed as shown below (Figure 2). The temperature at night falls below the maximum temperature set for that particular poly tunnel to represent the diurnal variation. However, the temperature maintained inside the poly tunnels was always higher than the ambient temperature; therefore temperature stress was forced on the plants during day time while there was photosynthetic activity (Figure 2).

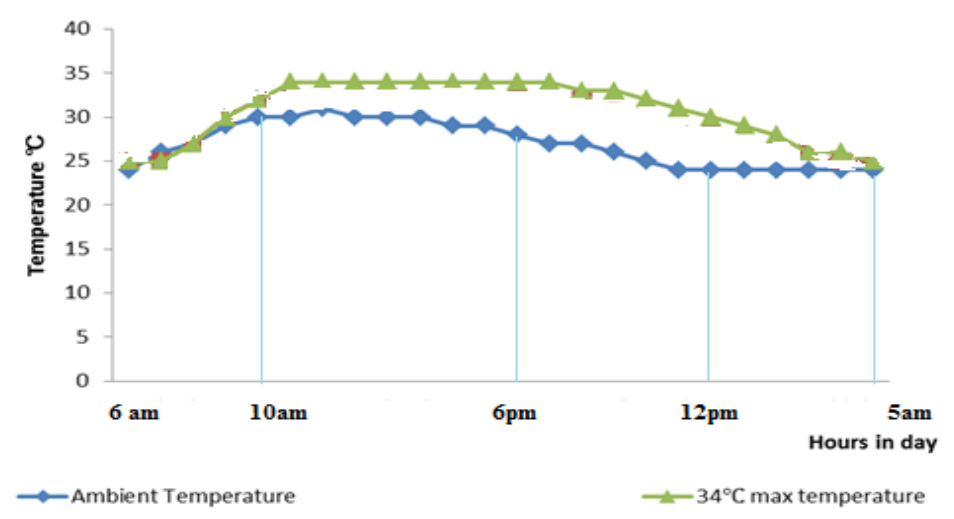

Figure 2. Temperature variations inside and outside the poly tunnel 


\section{Plant Growth Parameters}

Plant growth parameters were investigated weekly during the study period. Data was recorded from the vegetative growth up to the fresh green tender pod yield. To obtain sample of pods of uniform maturity, blossoms were tagged with colored wool at the beginning of full bloom. Plant heights and number of flowers were determined by nondestructive sampling at a weekly basis during vegetative and flowering period of the crop. Germination percentage (Survival rate) was estimated by the percentage of plants that germinated from the seeds as follows:

Germination percentage $=\frac{\text { No of Seeds Germinated }}{\text { No of seeds sown }} \times 100$

Total number of flowers was counted following tagging method. Plant height was measured at weekly intervals up to 6 WAP from the surface of the soil to the tip of the highest leaf. The weight of pods developed from tagged flowers was measured. The length of pods developed from tagged flowers was measured using a ruler.

Soil sampling was performed twice every season of the experiment. First sampling was done 10 weeks after planting and, second sampling was done after crop harvesting. Soil samples were taken from $10 \mathrm{~cm}$ below the surface of each pot using a soil sampler. Composite samples were prepared accordingly and each pot has 3 composite samples. Soil $\mathrm{pH}$ and EC were measured preparing soil solutions using $\mathrm{pH}$ and electrical conductivity meter.

\section{Data Analysis}

The experimental design was Completely Randomized Design (CRD) with factorial treatment structure. Temperature and mulches were taken as factors. All extraction runs and analysis were carried out at least in duplicate and in randomized order with the mean values. For each treatment five replicates were used to deduce the random error. Analysis of covariance (ANCOVA) of the results was performed using General Linear Model procedure of Mini tab (Software Version 
17) Multiple comparison of the various means were carried out by LSD

\section{Results and Discussion}

\section{Soil Parameters}

\section{Soil pH}

Average soil $\mathrm{pH}$ among the treatments ranged from 6.3-6.8 (Figure 4.). Average soil $\mathrm{pH}$ among the treatments ranged from 6.4-6.8 (Figure 4). Generally, plants mulched with saw dust and straw maintained near (6.7-6.8) to the neutral $\mathrm{pH}$ values than the others $(\mathrm{p}<0.05)$. Soil $\mathrm{pH}$ is lowest in plants mulched with coir dust (6.4). In sawdust mulch, the $\mathrm{pH}$ was maintained at 6.8 which is near to the neutral $\mathrm{pH}$ even in the stressful conditions. Lower soil $\mathrm{pH}$ increases the solubility of $\mathrm{A} 1, \mathrm{Mn}$ and $\mathrm{Fe}$ which can be toxic and therefore, limit root growth. Neutral $\mathrm{pH}$ encourages the decomposition rate (Kemmitt et al., 2005) and it is also the preferred soil $\mathrm{pH}$ range for good growth and optimum yield of common crops. It was reported that the best $\mathrm{pH}$ range for Okra is 6.5-6.8 (Kemmitt et al., 2005).

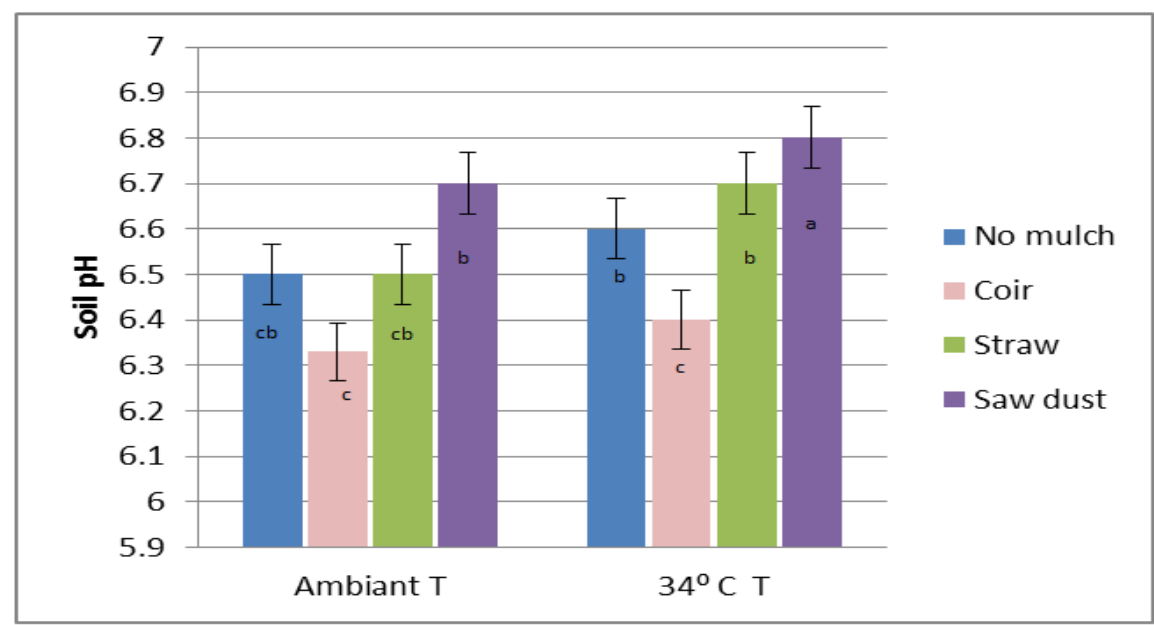

Figure 4. Effect of coir dust, straw and saw dust as mulch on soil $\mathrm{pH}$ 


\section{Soil Electrical Conductivity (EC)}

Average soil EC among the treatments ranged from 0.07-0.09 dS/m (Figure 5). According to the results, EC decreases with increasing temperature. But there is a significant difference $(p<0.05)$ between mulched and no mulched treatments. The highest EC was reported from coir dust treatment in ambient temperature followed by straw and then saw dust mulch. In stressful temperature $\left(34{ }^{\circ} \mathrm{C}\right)$ treatments, the lowest EC was shown from no mulch condition and the highest was obtained in saw dust mulch. Agricultural management practices can change the temperature of the soil surface and influence the hydrothermal properties of the soil. For example, mulching can affect the temperature and moisture content of the soil. EC is proportionally increased with the moisture content (Li et al., 1999).

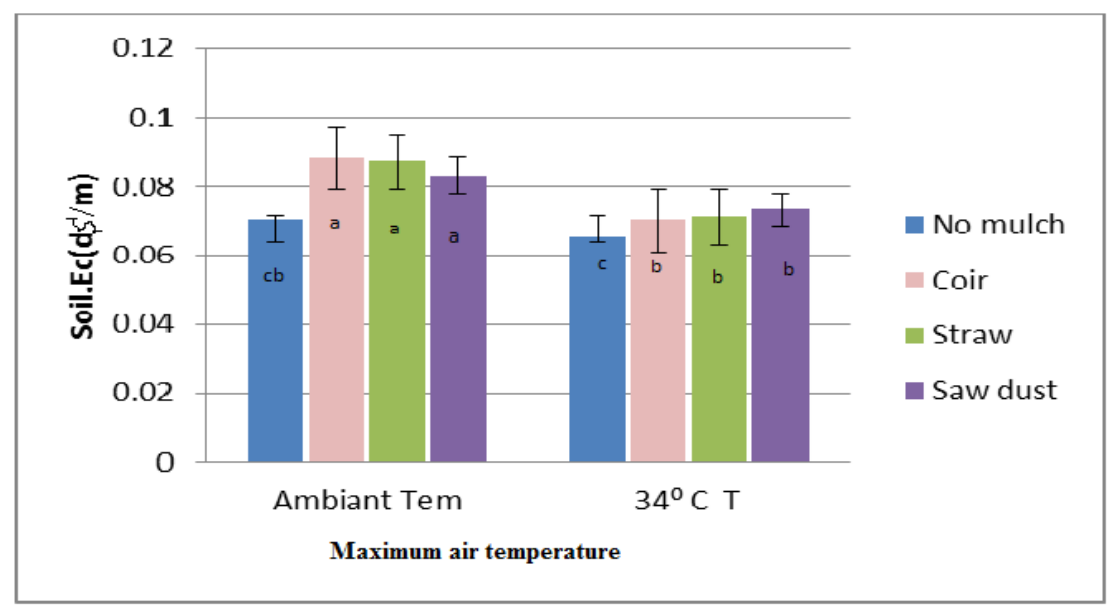

Figure 5. Effect of coir dust, straw and saw dust as mulch on soil electrical conductivity

\section{Growth and Yield Parameters of Red Okra}

\section{Percentage of the Germination}

Mulches significantly $(\mathrm{p}<0.05)$ affected the germination of Red Okra seeds respective of the temperature. Seedling emerging rate was significantly reduced by no mulch condition in both temperature 
treatments 2 weeks after seeding (Figure 6). Similarly, Sharma (1976) explained that limiting soil water content and extreme temperatures are the major stresses which constrain seed germination in arid and semiarid regions. Germination is the period which requires the highest water potential. Temperature also appears to determine the optimal and minimum water potentials for germination of several species (Sharma, 1976).

In addition, individual effect of the temperature stress has significant influence on the germination at 0.05 probability level. Temperature stress effect may reduce the probability of seedling establishment because of the effect of high temperature results in low soil water conditions, and the effect on seedling growth and survival of seedlings (Gunawardana et al., 2011).

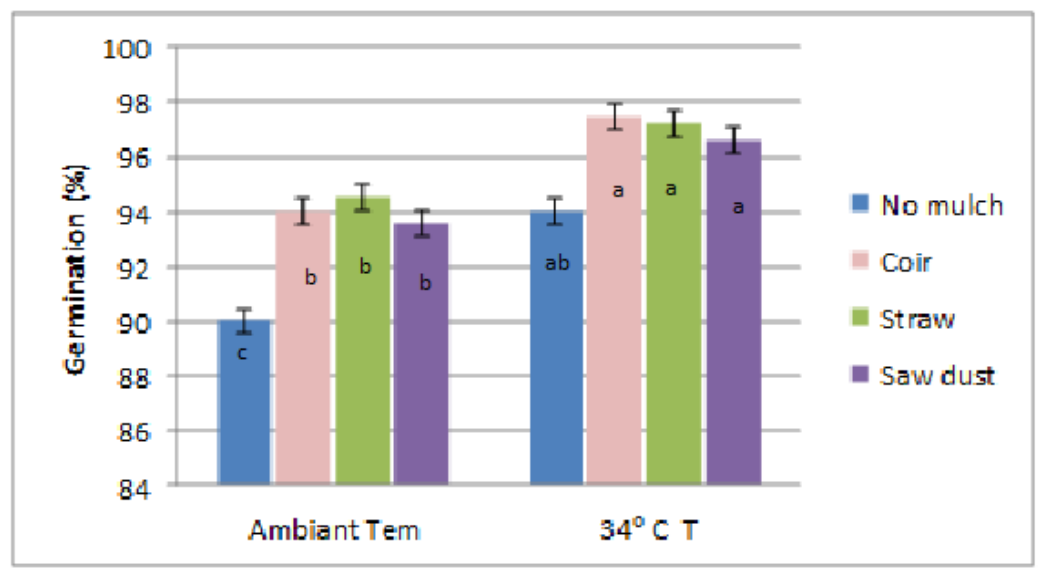

Figure 6. Effect of treatments on percentages of the germination

\section{Plant Height}

Average plant height among the treatments ranged from $64-74 \mathrm{~cm}$ (Figure 7). Generally, height of the plants maintained in $34{ }^{\circ} \mathrm{C}$ maximum temperature is significantly higher than that of ambient temperature $(\mathrm{p}<0.05)$. High temperature induces rapid growth and therefore, the plant height is significantly high in plants grown in 34 ${ }^{\circ} \mathrm{C}$ maximum temperature poly tunnel which agrees with Ravinder et al., (1997). Further, $34{ }^{\circ} \mathrm{C}$ maximum temperature poly tunnel height of the plants mulched with sawdust was highest followed by coir 
dust and straw. Plants grown in no mulch condition was lowest in height.

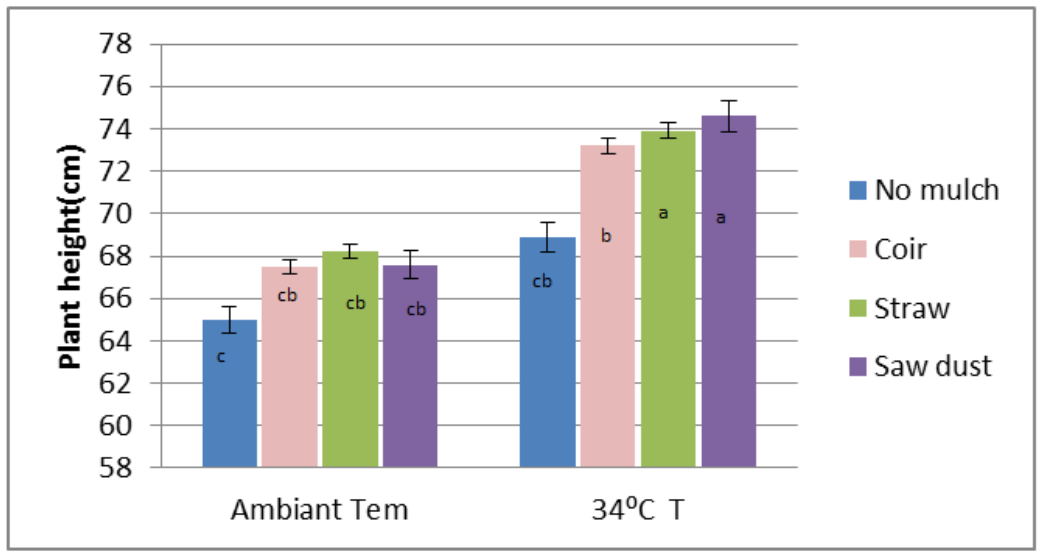

Figure 7. Effect of treatments on average plant height

\section{Number of Flowers}

The Red Okra started to flower 3, 4 weeks after sowing (Figure 8). Among the treatments, the number of flowers/plant was counted up to 3 weeks from the first flowering. The highest number (10) of flowers was observed in $34{ }^{\circ} \mathrm{C}$ temperature poly tunnel under saw dust and straw mulched condition, compared to no mulch (Figure 8). However, Green Okra variety Haritha produced only 8 flowers in 34 ${ }^{\circ} \mathrm{C}$ temperature without water stress condition (Gunawardena et al., 2011). There was no significant difference $(p>0.05)$ in the number of flowers due to the effect of mulch. But the individual effect of temperature has significant influence except in no mulch and coir dust mulch condition according on the flowering. It showed that the Red Okra (indigenous variety) performed better than Green Okra (variety Haritha) experimented in the same condition under stressful temperature conditions without mulch treatments. 


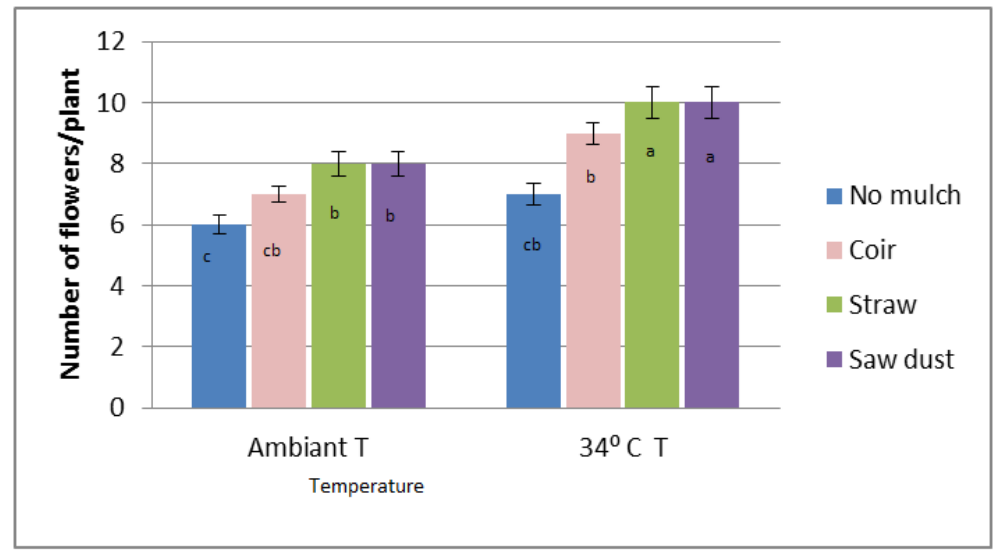

Figure 8. Effect of treatments on average number of flowers per plant

\section{Pod lengths}

Average pod length of Red Okra among the treatments ranged from $17.8-21.2 \mathrm{~cm}$ (Figure 9). Pod length of the plants maintained in 34 ${ }^{\circ} \mathrm{C}$ temperature with coir and straw mulches are significantly higher than that of the others $(\mathrm{p}<0.05)$. Pod length is lower in plants grown in ambient temperature than $34^{\circ} \mathrm{C}$. However, pod length in plants mulched with coir dust and straw mulch were found to be greater than the other mulch types in stressful temperatures.

The pod length was increased slowly in the first three days of development, and then increased rapidly until the eighth day when those plants grow in the ambient environment. Similarly, Ketsa and Chutichudet (1994) showed that pod length increased rapidly until the eighth day. Pods showed rapid development when they were exposed to the high temperature stress with no water stress condition. 


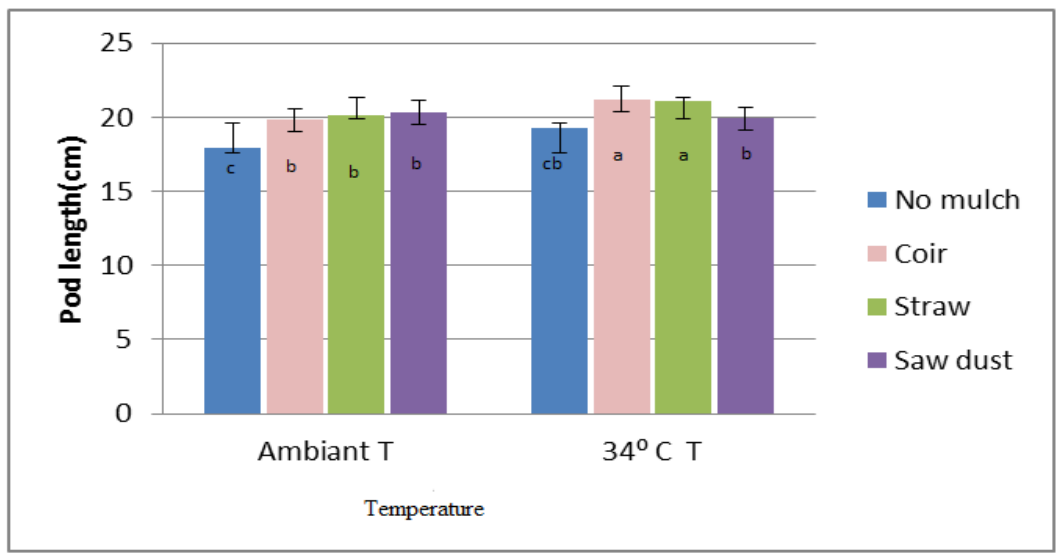

Figure 9. Effect of treatments on average pod length

\section{Number of pods per plants}

The highest number of fruit/ pod per plant (9) was found with high temperature $\left(34^{\circ} \mathrm{C}\right)$ with saw dust and straw mulches and the lowest number of pods was observed in no mulch condition at both high temperature $\left(34^{\circ} \mathrm{C}\right)$ and the ambient temperature treatments (Figure 10). But, the highest number of pods in Green Okra (variety Haritha) was less than 7 (Gunawardena et al., 2011). Drought or temperature stress occurring during vegetative growth period is called the vegetative phase drought. This type of drought affects plant's assimilatory organs, which usually decrease in number and size as a result of lower photosynthetic production (Kaiser, 1987). This study shows that proper soil and water management even at stressful temperature can improve the number of pods/fruits per plant of Red Okra.

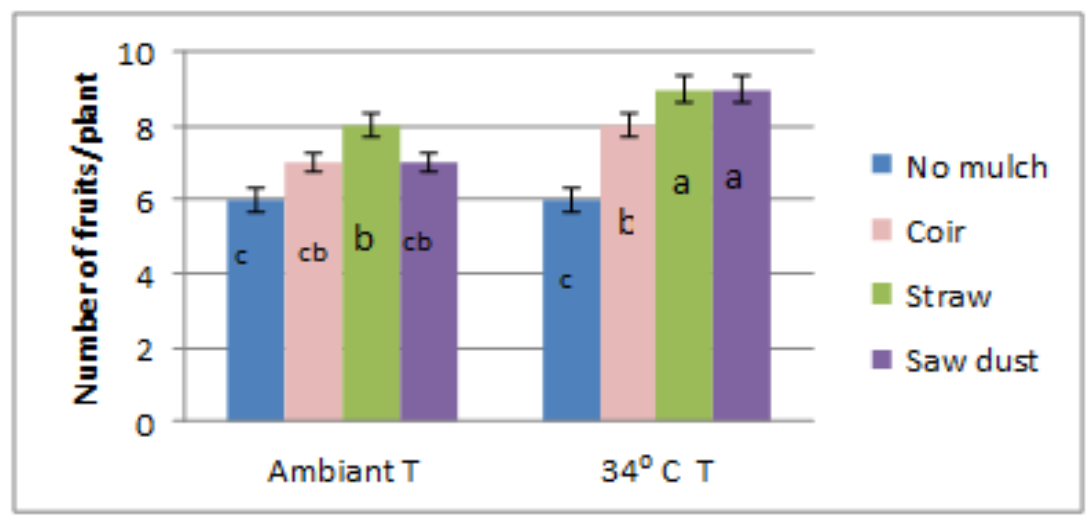

Figure 10. Effect of treatments on average number of fruits per plant 


\section{Pod Yield}

The number of pod and pod weight are important yield components of Red Okra to achieve highest yield (Figure 11). Results indicate the effect of individual mulches on yield (Table 2). In Green Okra (variety Haritha) pod yield reduces proportionately with the temperature because variety Haritha produced pods less than $30 \mathrm{~g}$ of average weight (Gunawardana et al., 2011). But in Red Okra, pod yield was high with mulch when it was exposed to $34^{\circ} \mathrm{C}$ temperature comparing with no mulch condition. Highest yield of Red Okra was obtained in $34{ }^{\circ} \mathrm{C}$ temperature with straw mulch. Red okra reached the highest average pod weight of $38 \mathrm{~g}$ with straw mulch and $37 \mathrm{~g}$ in saw dust and coir mulches even at stressful temperature.

Further, the results of Red Okra showed that under ambient temperature, Red Okra pods could be harvested 7 to 9 days after full blooming. Whereas, when there is temperature stress such as $34^{\circ} \mathrm{C}$ Red Okra pods could be harvested 5 to 6 days after full bloom when the pod length is about $20 \mathrm{~cm}$ which is a good marketable size. But in Green Okra (variety Haritha), when there is temperature stress $\left(34{ }^{\circ} \mathrm{C}\right)$ pods have to be harvested on 5-6 days but the length is less than $10 \mathrm{~cm}$ which does not attract a good market price. This study has shown that even in the Red Okra pods harvested earlier than normal in high temperature $\left(34^{\circ} \mathrm{C}\right)$, the yield was $37 \%$ higher than the pods grown under ambient temperature. This may be due to the fact that vigorous growth and development of Red Okra in the higher temperature conditions has lead to this production. It proves that Red Okra can perform well in stressful temperature by using mulches to resist the effect of high air temperature on soils. Cultivating Red Okra with straw mulch to ensure a higher number of pods and higher pod weight could be a valuable adaptation measure for farmers facing high air temperature stress due to global warming. 


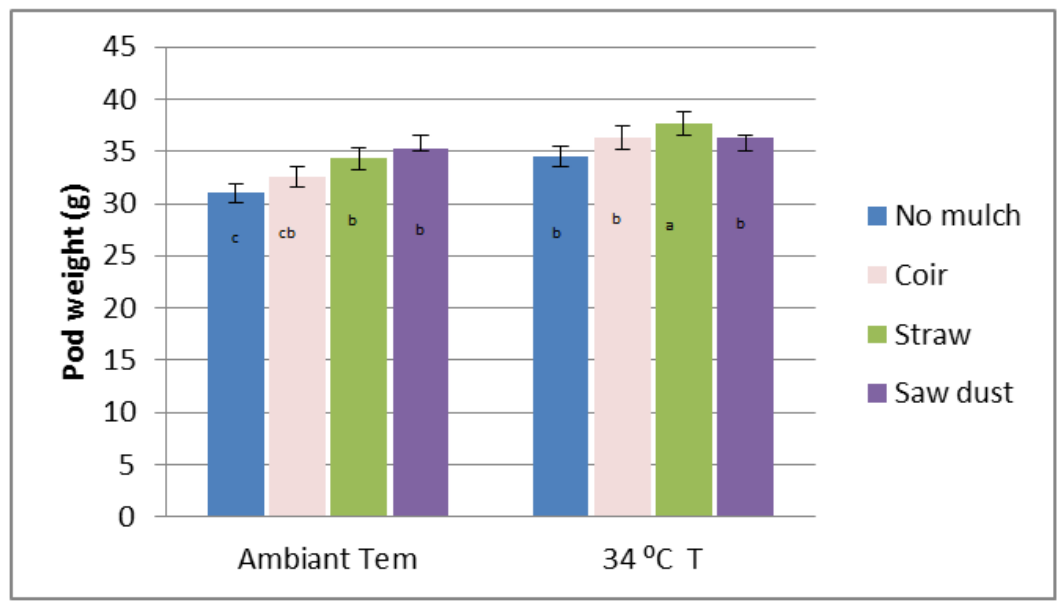

Figure 11. Effect of treatments on the average fresh pod weight

Table 2. Mean values of growth and yield parameters of Red Okra under deferent treatments.

\begin{tabular}{|c|c|c|c|c|c|c|c|c|c|c|c|c|c|}
\hline \multirow[t]{2}{*}{ Treatments } & \multicolumn{3}{|c|}{ Pod weight (g) } & \multicolumn{2}{|c|}{ Germination (\%) } & \multicolumn{2}{|c|}{ Plant height $(\mathrm{cm})$} & \multicolumn{2}{|c|}{ Number $f$ fruits } & \multirow{2}{*}{\begin{tabular}{|l|} 
soil pH \\
mean \\
\end{tabular}} & \multirow{2}{*}{ std } & \multirow{2}{*}{\begin{tabular}{|l|} 
Soil Ec \\
mean \\
\end{tabular}} & \multirow{2}{*}{$\begin{array}{l}\text { (ds/m) } \\
\text { std }\end{array}$} \\
\hline & & mean & std & mean & std & mean & std & mean & std & & & & \\
\hline \multicolumn{2}{|c|}{ Ambient tem-no mulc } & & \pm \pm 0.3878 & 90 & \pm 0.215090 & 6 & $5 \pm 4.733920$ & & \begin{tabular}{l|l}
$6 \pm 0.215090$ \\
\end{tabular} & 6.5 & \pm 0.063245 & 0.08 & \pm 0.224499 \\
\hline \multicolumn{2}{|c|}{ Ambient tem-coir } & 32. & $5 \pm 0.24498$ & 94 & \pm 0.425365 & 67. & \pm 2.416609 & & $7 \pm 0.425365$ & 6.3 & \pm 0.332264 & 0.088 & \pm 0.256124 \\
\hline \multicolumn{2}{|c|}{ Ambient tem-straw } & 34. & \pm 0.01354 & 94.5 & \pm 0.389378 & 68. & $2 \pm 3.852272$ & & $8 \pm 0.389378$ & 6.5 & \pm 0.666333 & 0.087 & \pm 0.292574 \\
\hline \multicolumn{2}{|c|}{ Ambient tem-saw dus } & 35. & $3 \pm 0.00030$ & 93.6 & \pm 0.244981 & 67. & $6 \pm 4.319326$ & & $7 \pm 0.244981$ & 6.7 & \pm 0.025612 & 0.083 & \pm 0.116619 \\
\hline \multicolumn{2}{|c|}{34 o c max tem-no mul } & 34. & $5 \pm 0.31240$ & 94 & \pm 0.076164 & 68. & \pm 4.720151 & & $6 \pm 0.002135$ & 6.6 & \pm 0.630891 & 0.065 & \pm 0.332307 \\
\hline \multicolumn{2}{|c|}{34 o c max tem-coir } & 36. & $3 \pm 0.00580$ & 97.5 & \pm 0.253574 & 73. & $2 \pm 5.462600$ & & $8 \pm 0.000303$ & 6.4 & \pm 0.259729 & 0.07 & \pm 0.185472 \\
\hline \multicolumn{2}{|c|}{$340 \mathrm{~cm}$ max tem-straw } & 37. & $6 \pm 0.285$ & 97.2 & \pm 0.457537 & 73. & \pm 1.638883 & & \begin{tabular}{l|l|}
9 & \pm 0.003124 \\
\end{tabular} & 6.7 & $7 \pm 0.319183$ & 0.071 & \pm 0.285 \\
\hline \multicolumn{2}{|c|}{34 o c max tem-saw du } & 36. & \pm 0.21260 & 96.6 & \pm 0.145 & 74. & $6 \pm 3.034798$ & & $9 \pm 0.005805$ & 6.8 & \pm 0.564269 & 0.072 & \pm 0.291260 \\
\hline
\end{tabular}

\section{Conclusions}

According to the results, in stressful temperature $\left(34{ }^{\circ} \mathrm{C}\right)$, neutral $\mathrm{pH}$ maintained in saw dust mulch improves the soil nutrient availability and root as acidic $\mathrm{pH}$ conditions create toxic conditions. Highest EC was observed in stressful temperature with saw dust mulch which improved the water content and minimized the water stress conditions. Further, the highest plant height was observed in stressful temperature with saw dust mulch which encourages good vegetative growth. Number of flowers of Red Okra (10) was highest in saw dust and straw mulch at temperature stress conditions but Green Okra (Haritha) produced only 8 flowers at the same experimental conditions without mulch treatment (Gunawardana et al., 2011). Further, under ambient temperature, Red Okra pods 
could be harvested 7 to 9 day after full blooming. Whereas, when there is temperature stress such as $34{ }^{\circ} \mathrm{C}$, Red Okra pods could be harvested on 5 to 6 days after full bloom the pods were about $20 \mathrm{~cm}$ length which have a good market value. This study has showed even the Red Okra plants are exposed to temperature stress, pods harvested earlier than normal has the yield 37\% higher than the pods grown under ambient temperature. Whereas in Green Okra (varity Haritha) pods have to be harvested 5-6 days when exposed to high temperature and the pod length was just 7-8 cm (Gunawardana et al., 2011). Usually the small size Okra pods are not preferred by consumers as the edible part is less.

As global warming may not be controlled, careful planning of Red Okra cultivation with straw mulch will increase the yield even when there is temperature stress to plants growth. This may be due to the fact that vigorous growth and development of Red Okra in the higher temperature conditions lead to this production. This study shows that Red Okra could be a good adaptation measure for dry zone farmers when the temperature stress is a limiting factor for higher productivity by reducing the high air temperature effect on soils by using straw mulch. Straw is freely available in the dry zone and it could be a viable adaptation measure for farmers.

\section{References}

Adebooye, O. C. and Oputa, C. O. (1996). Effects of galex on growth and fruit nutrient composition of okra (Abelnurschus esculentus). Ife J. Agric. 18 (1\&2): 1-9.

De Silva, C.S., (2006). Impact of climate change on potential soil moisture deficit and its use as a climate indicator to forecast irrigation need in Sri Lanka, Water Professionals' Day symposium-2006, Post graduate Institute of Agriculture (PGIA), University of Peradeniya, Sri Lanka, pp.79-90.

Gunawardhana, M.D.M., De Silva C.S and Godawatta V.N.A., (2011). Impact of temperatureand water stress on growth and yield of selected crops. International Conference on Impact of Climate Change on Agriculture, University of Ruhuna, Mapalana Kamburupitiya. Dec 20 th 2011, pp 150-157. 
IPCC (2001). Intergovernmental Panel on Climate Change, Third Assessment Report The Scientific Basis Cambridge University Press.

Kaiser, W.M., (1987). Effects of water deficit on photosynthetic capacity. Physiologia Plantarum (71): pp142-149. http://dx.doi.org/10.1111/j.1399-3054.1987.tb04631.x

Ketsa, S., and Chutichudet, B.,(1994). Pod growth, development, biochemically changes and maturity indices of Okra cv. small scale vegetable production and economics Acta Horticulture. pp 369

Kuepper .G., (2008) .Growing Heirloom Okra at the Kerr Center a Preliminary Study, November 2008 by sustainable agriculture specialist.

Li F.M., Guo A.H., and Wei H., (1999). Effects of plastic film mulch on yield of spring wheel. Field Crop RES., 63:pp79-86 http://dx.doi.org/10.1016/S0378-4290(99)00027-1

Ravinder, K., Srivastava, B. K. and Kumer, R., (1997), Effect of different mulch materials on the soil temperature and moisture in winter tomato. CropRes., 14, pp137-141.

Sharma, S., Rangger, A., von L tzow, M. \& Insam,H., (1998). Functional diversity of soil bacterial communities increases after maize litter amendment. European Journal of Soil Biology. 34, pp 53-60. http://dx.doi.org/10.1016/S1164-5563(99)90001-8

Received: 22-1-2016 Revised: 20-05-2016 Accepted: 24-05-2016 